\title{
Risk Sharing and Stand-Alone Pension Schemes
}

\author{
Arij Lans Bovenberg \\ Netspar, Tilburg University, P.O. Box 90153, Tilburg, 5000 LE, The Netherlands. \\ E-mail: A.L.Bovenberg@uvt.nl
}

Pension schemes increasingly are stand alone, in the sense that they lack a risk-absorbing sponsor in the form of the government or corporations. This paper describes various principles for how stand-alone pension schemes should optimally share risks among participants and trade risks on capital markets. In this connection, it discusses the optimal liability structure of pension funds, the optimal link between retirement and longevity and the role of longevity bonds in sharing demographic risks across generations. The paper also highlights the need for labor-market reforms that enhance the accumulation and maintenance of human capital and allow the speed and time of retirement to act as a way to buffer risk.

The Geneva Papers (2007) 32, 447-457. doi:10.1057/palgrave.gpp.2510143

Keywords: pension schemes; risk; labor market; human capital

\section{Introduction}

All over the world retirement systems are under severe pressure. Public pay-as-you-go (PAYG) schemes in continental European countries are especially vulnerable to lower fertility because they rely on human capital of the young to finance the pensions of older generations. As generations invest less in the human capital of the next generations by reducing fertility, they should invest more in financial capital. Hence, lower fertility calls for gradually shifting from PAYG financing to funded pension schemes. ${ }^{1}$ Several countries with large PAYG systems are thus focusing the public scheme more on poverty alleviation by gradually reducing earnings-related PAYG benefits for those earning higher incomes.

At the same time, several developments have led to the demise of corporate definedbenefit plans in which companies guarantee fixed pension benefits by absorbing all financial market and demographic risks. First of all, ageing of the members of the schemes has expanded the obligations of the schemes compared to the premium base (see Figure 1). With the financial and actuarial risks of pension obligations thus starting to dominate the risks of their core business, companies no longer want to underwrite the risks of their pension schemes. Moreover, in an increasingly competitive and dynamic world economy, firms are able to offer less security to their employees. Indeed, the increased bankruptcy risk of sponsoring companies implies that workers with defined-benefit claims are saddled with the substantial credit risk of the company for which they work. Finally, new accounting rules force companies to

\footnotetext{
${ }^{1}$ See Sinn (2000).
} 


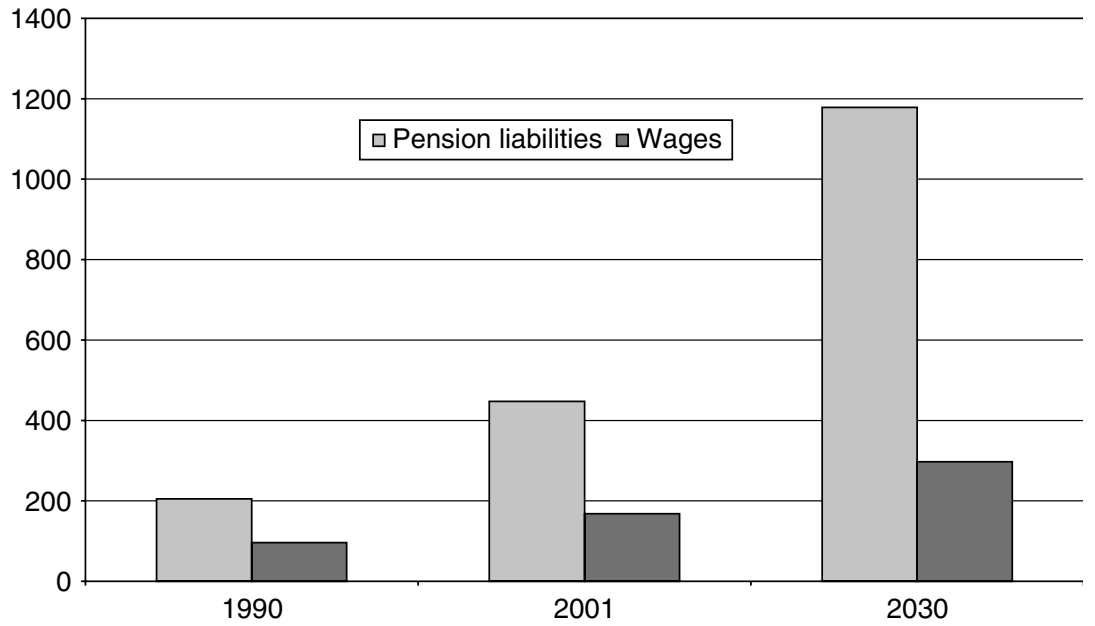

Figure 1. Liabilities and premium base of Dutch pension funds in millions of euros, 1990-2030. Source: Westerhout et al. (2004).

disclose their pension obligations on a market basis. This is another stimulus for companies to get out of the pension insurance business.

As a result of these developments, pension schemes increasingly are stand alone - in the sense that they lack a risk-absorbing sponsor in the form of the government or corporations. Pension schemes thus face a hard budget constraint so that the members of the scheme become the explicit risk bearers; they have to either share risks among themselves or shift risks to others by trading financial instruments on capital markets. Hence, stand-alone pension funds can still provide defined-benefit types of pension promises by buying guarantees in financial markets or by finding participants who are able to guarantee pension payments to other participants. In any case, the retreat of governments and companies as sponsors of pension systems calls for institutional innovation in pension insurance in general, and risk sharing in particular. This paper describes various principles for how stand-alone pension schemes should optimally share risks. These principles are relevant for pension financing around the world. ${ }^{2}$

The rest of this paper is structured as follows. The following section elaborates on the importance of agreeing on explicit risk-sharing contracts before risks actually do materialize. The next section discusses how stand-alone pension schemes can optimally share financial-market risks among participants. The case of longevity risk is explored in the following section. The penultimate section turns to a discussion of labor-market reform as a way to allow workers to absorb more risks. The final section concludes.

\footnotetext{
${ }^{2}$ Bovenberg (2007) applies these principles to Dutch sectoral pension funds, which have been evolving in the direction of stand-alone pension funds. The analysis reveals several major remaining challenges facing the Dutch pension funds.
} 


\section{Complete contracts on risk sharing}

Explicit agreements about how members share risks are becoming more important for several reasons. First, being the residual risk bearers in pension plans, members should be informed about what risks they face so that they can take this into account in their own financial planning. Second, risks increase as pension funds become mature and as members age (see Figure 1). The way these risks will be shared is thus increasingly important for the members.

Making explicit agreements about how risks are shared before the shocks actually materialize (i.e., implementing state-contingent rules) also prevents costly political conflicts when the shocks hit. These risk-sharing rules thus alleviate political risks and pension-related anxiety among workers. Moreover, sharing risks ex ante allows for contracts that are advantageous for all parties (i.e., giving up resources in one contingency is traded with receiving resources in another contingency). After the shock (i.e., ex post, when the contingency that actually materializes is known), in contrast, one of the parties has to give up resources. Insurance then becomes redistribution. Finally, explicit risk sharing on the basis of complete contracts avoids litigation, which is often the result of ambiguous, incomplete risk-sharing agreements and which generates additional transaction costs.

In designing state-contingent rules, pension funds face a trade-off between commitment and flexibility. On the one hand, pension funds may want to create clarity ex ante about how risks are shared for the reasons described above. On the other hand, funds may want to leave some discretionary powers so that they can respond to unforeseen shocks. This latter flexibility implicit in incomplete contracts requires, however, that participants trust the governing board to act in the interests of the participants. This requires professional governance to reduce agency costs.

\section{Sharing financial-market risks optimally}

Pension funds allow generations to share financial-market risks. As an illustration, in traditional final-pay schemes, young workers share in financial-market risks faced by the older members through the so-called recovery premia. In the case of an adverse financial shock, pension premia are raised so as to contain the decline in pension benefits paid out to retirees, to protect the pension rights of the workers and to reduce the resulting funding deficit. In a defined-benefit scheme with guaranteed real retirement benefits that carries mismatch risk because of investments in risk-bearing assets, the active participants (i.e., the workers who pay premia into the fund) in effect borrow from the older, retired members by issuing real bonds to these older members, and use the funds to invest in the risk-bearing assets. In fact, the risky pension contributions produced by the mismatch risk allow the young generations to take over financial-market risks from the older generations. ${ }^{3}$ Reliance on fluctuating recovery pension premia to implement intergenerational risk sharing is increasingly costly, however, in terms of adverse demand- and supply-side effects. This is especially so

\footnotetext{
${ }^{3}$ See Beetsma and Bovenberg (2006).
} 
because the ageing of the members of pension schemes demands larger changes in contributions to contain fluctuations in pension benefits because pension obligations expand compared to the premium base (see Figure 1).

Some pension schemes contain the fluctuations in recovery premia by restructuring portfolios to match the guarantees in defined-benefit pension plans - the so-called liability-driven investment. A shortcoming of liability-driven investment with secure pension liabilities is that young individuals fail to take advantage of the risk premium of equities. By shifting financial risks to other parts of the financial system, pension funds cannot act as a stable long-term investor on behalf of participants and members with a long-run investment horizon. Defined-benefit pension schemes should therefore restructure their liabilities rather than simply restructure their assets to better match these. Collective pension schemes should thus think hard about determining the optimal liability structure from the point of view of the members, now that sponsors and participants are less willing or able to guarantee benefits at low implicit prices.

Efficient risk sharing implies that an adverse shock causes consumption of all agents to decline by the same percentage. ${ }^{4}$ Risks are thus shared as broadly as possible. With permanent income-determining consumption, everybody's wealth should thus decline by the same percentage after a negative shock. The most important components of aggregate wealth of individuals are pension wealth, housing wealth and human wealth (i.e., the discounted value of future labor income). For younger workers, human wealth is the most important wealth component. For older members, in contrast, pension rights account for most of the individual wealth. In fact, retirees have (almost) completely depreciated their human capital. Hence, in order to achieve the same relative change in overall wealth for all cohorts (as required by optimal risk sharing), the pension wealth of young cohorts should fluctuate more than that of older generations if a shock hits the pension schemes. ${ }^{5}$ Whereas pension rights for younger generations are relatively uncertain (i.e., the system resembles a defined-contribution system), pension rights are less risky for the elderly. As individuals grow older, they thus transform their defined-contribution claims into defined-benefit claims.

Adapting pension rights in this way allows financial risks to be shifted to younger generations without having to rely on the recovery premium instrument. Compared to an occupational pension scheme in which the sponsoring firm absorbs the risks, the young members take over the risk-bearing role of the sponsor (or the shareholders of the sponsoring firm) in a stand-alone pension scheme. Whereas younger members lose guarantees, they should be compensated by more upward potential. In this way,

\footnotetext{
${ }^{4}$ This assumes that all agents feature the same constant relative risk aversion and that utility is timeseparable and separable in consumption of commodities and leisure. More generally, optimal risk sharing implies that everyone's marginal utility changes by the same percentage after a shock hits. See Bohn (2005).

${ }^{5}$ These arguments for different types of claims on pension funds of young and old become even stronger with habit formation. In that case, the young have more time to adjust their habits and thus should be able to take on more risk than the old. Loss-aversion preferences also strengthen these arguments (see Bernatzi and Thaler (1995)). If agents exhibit loss aversion, the costs of risky investments rise less rapidly than the benefits of doing so (see Bovenberg et al. (2007)). Hence, hard guarantees are rather expensive for young agents in view of their long horizon. For older, loss-averse agents with shorter horizons, risk-bearing assets are less attractive.
} 
pension contributions become part of the labor reward rather than being a tax or subsidy on work. Additional pension rights are priced actuarially fairly: workers get back the monetary value of their contributions in the market value of their pension rights. This eliminates the implicit tax or subsidy component in the pension contribution, thereby enhancing labor-market efficiency.

Exploiting the long horizon of young workers to buffer shocks enhances also macroeconomic stabilization. Indeed, the marginal saving propensity out of pension wealth is smallest for young households exhibiting long horizons and substantial human capital. In particular, it reduces the tension between facilitating macroeconomic stabilization and enforcing the discipline of markets, which tend to be cyclical. In particular, by letting the pension obligations to young workers fluctuate more with interest rates and risk premia (and thus taking advantage of the long recovery horizon of young workers), we limit the pro-cyclical effects of the discipline of mark-to-market valuation. Young members should in fact be stable long-term investors who are in the best position to absorb financial-market volatility.

The hybrid system of both defined-contribution and defined-benefit elements laid out in this section can be viewed as a pension scheme that has on the liability side of its balance sheet both soft equity claims (or junior claims) and hard debt claims (or senior claims). The active members who are not yet retired, and especially the young members who still have substantial human capital, hold most of the soft claims and are thus in fact the residual risk bearers of the scheme. The retired generations own more secure claims in the form of debt. ${ }^{6}$ This hybrid system is consistent with optimal investment behavior over the life cycle. ${ }^{7}$ Young agents invest more in risk-bearing assets because most of their wealth consists of less risky human capital if agents feature constant relative risk aversion. As agents grow older, they move more into secure assets, which are preferably also protected against inflation. ${ }^{8}$ These arguments for diverging investment behavior of young and old become even stronger with habit formation. In that case, the young have more time to adjust their habits and thus should be more risk averse than the old.

If the older generations would hold most of the debt claims in accordance with the requirements for optimal intergenerational risk sharing, then the duration of the debtlike obligations of the pension schemes would fall. Hence, rather than adding high duration fixed-income assets to meet the duration of their fixed-income promises, pension schemes may want to reconsider the fixed-income promises to young members. Internal and external supervision should ensure solvency so that members who hold secure claims (mainly the old) are protected against bankruptcy. This supervision should thus ensure that the bond-like promises issued by the young members of the scheme to the older members are in fact credible.

\footnotetext{
${ }^{6}$ The retired generations may still find it optimal to have some exposure to stock market risk and longevity risk. Koijen et al. (2006) find that with plausible parameter values, retired agents should hold 20 percent of their pension wealth in equity.

${ }^{7}$ See Bodie et al. (1992).

${ }^{8}$ See Teulings and de Vries (2006).
} 


\section{Sharing longevity risk optimally}

A higher life expectancy raises the length of the inactive period that needs to be financed through retirement benefits. Hence, increased longevity puts financial stress on not only PAYG schemes but also funded pension schemes. In fact, if retirement ages do not adjust to higher life expectancy, funded pension schemes are particularly vulnerable. The reason for this is that the longer life spent in retirement calls for more financial saving, which depresses the return on capital. To prevent this stress on funded pension systems, higher life expectancy for cohorts younger than 65 years of age must go together with a higher retirement age (or lower annual benefits) for the cohorts concerned. ${ }^{9}$

A higher effective retirement age when longevity increases is crucial for several reasons. First of all, it maintains the return on funded pension systems by raising labor supply and thus containing the potential rise in the capital-labor ratio. It also raises the return on human capital by lengthening the horizon for investments in human capital. Indeed, a higher life expectancy calls for more accumulation, better maintenance and more intense use of human capital. Moreover, longer and deeper involvement in paid employment allows people to exploit their longer life to reconcile the two ambitions of, first, investing in the next generation as a parent and, second, pursuing a fulfilling career in paid work in which one keeps learning and applies new technologies.

A longer active working life also facilitates greater flexibility in employment patterns over the course of life for men and women alike by loosening the link between age and career progression. This reduces career pressure at the biologically determined time when parents care for young children, thereby promoting gender equality, fertility and child development. Parents of young children can continue to invest in the human capital of their children without having to depreciate their own human capital. Rearing children thus becomes less costly in terms of depreciated human capital of the parents. In this way, countries escape a vicious circle of early retirement and lower fertility in which politically stronger older generations favor generous passive spending on pensions and healthcare at the expense of investments in the human capital of younger generations.

If longevity shocks materialize only at older ages (at which time the cohort has already depreciated its human capital), then younger cohorts (who exhibit a longer horizon and more flexibility to adapt) should optimally share a larger part of these risks. A collective pension scheme can implement this particular way of sharing demographic risks between generations. In particular, the pension fund can promise an annuity to retirees while at the same time making the pension rights of the active members conditional on the capital that remains available after meeting these obligations to the retirees. The pension fund then in fact issues longevity bonds on behalf of the active members to the retired members. Pension funds thus, in effect, create new non-tradable assets that are not yet available on financial markets. Pension

\footnotetext{
${ }^{9}$ In fact, one can argue that all ages that are used to measure old age should be linked to longevity. In other words, one should measure old age from the end, rather than the beginning, of life.
} 
governance and pension supervision should ensure that these contracts between generations are not only beneficial ex ante but also can be enforced ex post (i.e., after financial and human capital risks have materialized). Immediate and thus continuous adjustment of pension rights to developments in capital and labor markets can help in this respect.

In addition to stimulating financial innovation, liquid markets for longevity-indexed bonds would help to establish objective market prices for longevity risk. This would assist regulators and help pension schemes in setting the terms of trade for internal risk trading between generations. Moreover, longevity bonds would allow members of a pension scheme to trade not only with other members in the same scheme but also with capital-market participants more generally. Indeed, there is a strong theoretical case for developing macro-markets for such contingent securities. ${ }^{10}$

In theory, governments can be providers of longevity bonds, as they are in a good position to shift this risk onto future and younger generations. These generations may be able to absorb these risks best through a longer working life associated with more human-capital investment. Governments, however, already bear substantial longevity risk on their balance sheets through public PAYG systems. Indeed, governments are able to issue longevity bonds on behalf of younger and future generations only if they reduce their exposure to longevity risk by linking the age at which these generations first receive their public pension to life expectancy. The rule of automatically linking public pensions to life expectancy avoids the political costs of discretionary decisions to limit eligibility to public pensions and tax benefits if longevity increases further. Agreeing on a risk-sharing rule ex ante also reduces the political risks associated with collective discretionary decision-making. Moreover, it allows individuals and firms to gradually adapt to a longer working life by better maintaining human capital and adjusting the organization of work. An increase in spending on disability pensions and unemployment benefits is thereby averted.

\section{Labor-market reform}

More flexible labor markets complement a longer and more flexible work life. Together with better-maintained human capital, they allow the speed and extent of phased retirement to act as a buffer for absorbing aggregate financial market and aggregate longevity risks. ${ }^{11}$ In an actuarially neutral pension system, working one year longer (and thus receiving annuities 1 year later) tends to raise the annual pension by about 7 percent. The speed and timing of retirement are thus a powerful instrument for absorbing risks. With workers able to absorb risk, pension funds can continue to supply risk-bearing capital, thereby boosting innovation and growth. We thus prevent the vicious circle of a risk-shedding scenario in which inflexible labor markets make

\footnotetext{
${ }^{10}$ See Shiller (2003).

${ }^{11}$ These ideas are closely related to those explored in the research program of the Geneva Association on the so-called fourth pillar supplementing the first three pillars of pension income. This fourth pillar involves income from (part-time) work to supplement or replace income from the first three, traditional, pillars (see Reday-Mulvey (2005)).
} 
workers unwilling to bear risk, and pension funds invest mainly in low-risk government bonds, thereby crowding out productive investments. ${ }^{12}$

Allowing the speed and time of retirement to act as an instrument to buffer risk requires adjusting the implicit labor contract, according to which workers are underpaid when young and overpaid later on. Indeed, increasing the retirement age at which the employer lays off the employee must not put undue strain on the employer. Employees should thus accept more wage flexibility over the life course (payment according to labor productivity; i.e. mark-to-market reward for labor) and internal flexibility in working practices (so as to protect their labor productivity at higher ages).

With a more flexible labor market for elderly workers, older workers bear less risk because they are less dependent on their firm surviving. The differences narrow between the insiders who are lucky enough to work for a surviving firm and the outsiders whose firms have not survived. Moreover, golden chains no longer tie older workers to their employer. This facilitates entrepreneurship and a more efficient allocation of labor. More generally, more flexible labor markets with new, flexible career patterns should allow young households to bear more risks by allowing these households to vary their labor effort depending on the shocks they have experienced throughout their lifetime. This requires European labor markets to become more inclusive, so that workers do not have to be continuously fulltime employed in order to enjoy a successful career.

In such a transitional labor market, the role of employers thus shifts from a riskbearing sponsor to the following: first, a facilitator of investments in human capital; second, an insurer of that human capital by protecting it; third, the creator of flexible work arrangements that allow elderly workers to adjust the speed and time of retirement to the pension rights and fourth, the creator of flexible career path and workplaces that allow young parents to invest in the human capital of their children without having to depreciate their own human capital.

Employers may also assist in creating collective pools for old age and other human capital insurances (such as disability and unemployment insurances) for their workers. By thus keeping the costs of these insurances under control, they improve their position on the labor market and reduce their wage costs. An important factor in determining the type of insurance and the optimal investments of the pension scheme is the type of human capital of the workers and the associated risks and possibilities to absorb risks by adjusting labor supply. This suggests that the pools should be homogeneous in terms of human capital. Moreover, the retirement plans should be closely integrated with human-resource management (HRM) of the employers.

Workers can absorb risks by varying not only labor effort but also consumption. Flexibility in premium rates allows agents to bear more risks and thus to benefit more from the rewards of risk taking. Indeed, after an expected shock, it is optimal to adjust consumption levels during the rest of one's lifetime. In effect, this involves spreading the risks over the longest possible recovery period. If the contribution rate is fixed $a$ priori, and does not respond to shocks, then the part of wealth that is dedicated to preretirement consumption does not contribute to risk sharing. Indeed, consumption

\footnotetext{
${ }^{12}$ See Boeri et al. (2006)
} 
Table 1 The welfare effects of various pension schemes

\begin{tabular}{lcccc}
\hline & First best $(\%)$ & DC $(\%)$ & DB $(\%)$ & No risk taking (\%) \\
\hline Welfare loss compared to first best & 0 & 6.1 & 5.2 & 9.1 \\
Average percentage of assets invested in stocks & 45 & 25 & 29 & 0 \\
Optimal contribution level & - & 19 & - & 21 \\
Optimal benefit level & - & - & 72 & 79 \\
\hline
\end{tabular}

Computations are derived on the basis of the model of Teulings and de Vries (2006), and the model parameters are as follows: riskless interest rate, 2 percent; equity premium, 4 percent; volatility of stock returns, 20 percent; parameter of risk aversion, 5; rate of time preference, 2 percent; duration of working period, 40 years and during of retired period, 20 years.

during the working life does not react to wealth shocks at all. Only the part of wealth that is dedicated to post-retirement consumption is exposed to stock-market shocks, which implies sub-optimal risk exposure.

In order to derive the welfare losses of a fixed contribution rate during the working period or a fixed benefit rate during the retired period, we solve a continuous-time lifecycle model along the lines of Teulings and de Vries. ${ }^{13}$ In this partial equilibrium model, an individual simultaneously optimizes her consumption and investment decision. The individual is assumed to have a working period of 40 years and subsequently a retired period of 20 years. During the working period, a constant and riskless wage income is earned. The individual maximizes expected lifetime utility with a subjective discount rate of 2 percent, and the instantaneous utility function features positive and constant relative risk aversion with a parameter of relative risk aversion of 5. The individual can invest in a risk-free asset and in risky assets. The risk-free rate equals 2 percent. Returns on the risky asset are lognormally distributed, with an expected annual return of 6 percent, while the volatility of returns amounts to 20 percent. We consider the cases where consumption levels for either the working period or the retired period are fixed at a predetermined constant level that is optimized. Welfare losses are measured in terms of certainty-equivalent consumption levels over the entire life cycle.

In the individual defined-contribution plan, where the consumption level during the working period is constant, the welfare loss is 6.1 percent compared to optimal risk sharing in which individual premia can respond to shocks (see Table 1). Simulations also show that the increased ability to adjust consumption during the working life allows for more risk taking. In particular, in a steady state, a pension scheme that optimally adjusts premia and benefits to shocks can invest 45 percent of its financial wealth in risk-bearing assets. In a pension scheme that fixes the premium at an optimal level of 19 percent of wage income, in contrast, this portfolio share is cut almost in half, to 25 percent.

\footnotetext{
13 Teulings and de Vries (2006).
} 
456

A defined-benefit scheme (which guarantees the benefit level irrespective of shocks) involves a welfare loss of 5.1 percent with a portfolio share of 29 percent in equity and an optimal fixed benefit level of 72 percent of annual wage income. If the pension scheme takes no risk at all, then the welfare costs are 9.1 percent (in terms of certaintyequivalent consumption) compared to the first best, while the contribution level is fixed at 21 percent.

\section{Conclusions}

The key challenges for institutional innovation in pension insurance are three-fold: first, to arrive at new, transparent risk-sharing arrangements that shift risks to households exhibiting long horizons and substantial human capital; second, to stimulate the maintenance of human capital and the flexibility of the labor market so that human capital is exploited better and can more effectively serve as a buffer for absorbing risk; and, third, to better diversify the human capital and financial capital of workers so that emancipated workers become less dependent on the firm for which they work. Indeed, the two main new securities of workers are, first of all, their employability and the associated capability to adjust to shocks in labor and financial markets and, second, stand-alone pension schemes with secure individual property rights that help agents exploit modern capital markets to diversify their investments and engage in efficient financial planning during the life cycle.

\section{References}

Beetsma, R.M.W.J. and Bovenberg, A.L. (2006) Pension systems, intergenerational risk sharing and inflation, Netspar discussion paper no. 2006-D020.

Bernatzi, S. and Thaler, R. (1995) 'Myopic loss aversion and the equity premium puzzle', Quarterly Journal of Economics 110: 73-92.

Bodie, Z., Merton, R.C. and Samuelson, W.F. (1992) 'Labor supply flexibility and portfolio choice in a life-cycle model', Journal of Economic Dynamics and Control 16: 427-449.

Boeri, T., Bovenberg, A.L., Coeuré, B. and Roberts, A. (2006) Dealing with the New Giants: Rethinking the Role of Pension Funds, Geneva Reports on the World Economy, CEPR and International Center for Monetary and Banking Studies.

Bohn, H. (2005) 'Who bears what risk? An intergenerational perspective', in D. Blitzstein, O. Mitchell and S.P. Utkus (eds) Restructuring Retirement Risks, Oxford: Oxford University Press.

Bovenberg, A.L. (2007) 'Frontiers in pension finance and reform: Institutional innovation in the Netherlands', in D. Broeders, S. Eijffinger and A. Houben (eds) Frontiers in Pension Finance and Reform, Cheltenham, UK: Edward Elgar Publishing.

Bovenberg, A.L., Koijen, R., Nijman, T. and Teulings, C. (2007) Saving and investing over the life cycle and the role of collective pension funds, Netspar panel paper.

Koijen, R., Nijman, T. and Werker, B. (2006) Optimal portfolio choice with annuitization, Netspar discussion paper 2006-D013.

Reday-Mulvey, G. (2005) Working Beyond 60 - Key Policies and Practices in Europe, Basingstoke, UK: Palgrave Macmillan.

Shiller, R. (2003) Macro Markets: Creating Institutions for Managing Society's Largest Risks, New York: Clarendon Press.

Sinn, H.W. (2000) 'Why a funded pension system is useful and why it is not useful', International Tax and Public Finance 7: 389-410.

Teulings, C. and de Vries, C. (2006) 'Generational accounting, solidarity, and pension losses', De Economist 146: $63-83$. 
Westerhout, E., van de Ven, M., van Ewijk, C. and Draper, N. (2004) To a robust pension system, CPB Document 67, The Hague, (in Dutch).

\section{About the Author}

Arij Lans Bovenberg is Scientific Director of Netspar, Tilburg University, and Professor in the Faculty of Economics and Business Administration at Tilburg University in the Netherlands. 